\title{
Culture Strategy as an Effort to Exist
}

\author{
Moh Rosyid ${ }^{1}$, Lina Kushidayati ${ }^{2}$ \\ \{mrosyid72@yahoo.co.id ${ }^{1}$, linakushidayati@iainkudus.ac.id²\} \\ IAIN Kudus, Kudus, Indonesia ${ }^{1,2}$
}

\begin{abstract}
This paper was written to describe the existence effort Jamaah Ahmadiyah Indonesia (JAI) in Colo Village, Dawe Distric, Kudus City, Central Java. The research data were taken from interview, observation, and literature were analyzed descriptively qualitatively. Result, JAI exsis since 1998 until now by 9 people. The early, conflic pasca vote head village in Colo village 1998. Losing group, create a group and give religious teaching Ahmadiyah. The existance JAI because (1) joint by nahdliyin business partner, (2) preacher assignment from central JAI from Bogor stay in Kudus to educated JAI, (2) JAI preacher attend culture invitation from nahdliyin, (3) adapted in culture nahdliyin although don't tradition in JAI, example read Yasin and tahlil in homes nahdliyin after dead, read Yasin in religious group once every week, (4) good bond family, friend, and neighbors, (5) obey the social norm and dont violate social, etic, and religious. The supported factor live peacefully, the nahdliyin is muslim abangan category, dont fanatic, and busy with work.
\end{abstract}

Keywords: Ahmadiyah; culture strategy; nirconflic

\section{Introduction}

Secte in religion always upto date for research, as Ahmadiyah in Islam. This paper description JAI in Kudus. JAI law legal at Minister of Justice's Decision No 5/23/1953 at 13 Maret 1953. Impact conflict, statement Ministry of Religion, Suryadharma Ali, 2011, give some alternative for JAI because the existance disturb and target conflick (a) becomes a lone secte take off islamic atribute, (b) back to Islam left there, (c) disbanded, (d) becomes indegenous religion (aliran kepercayaan), (e) new religions. agama baru karena keberadaannya dianggap bisul dan sasaran konflik. Eksistensce JAI development until Kudus City, Central Java consequence conflic pasca vote head village in Colo village 1998. The existance the response Islam abangan and the domination family, friendship, work mitra, and live in rural by tradition of nahdliyin.

20 th century the growth islamic movement in Indonesia, al-Jam'iyyah al-Khayriyah established 17 Juli 1905 in Jakarta, Jam'iyyatul Islah wal Irsyadil Arabi established 11 Agustus 1915 in Jakarta, Muhammadiyah established 12 November 1912 in Yogyakarta, Syarikat Islam established 1913, Nahdlatul Ulama established 31 Januari 1926, and Persis established 12 September 1923 in Bandung. The existance JAI in Indonesia until 1923. Each social organization in Islam have mass and basis. It is just, JAI conflick target because fanatisme ormas. At 1950 until 1970 some leader familiar by JAI but at 1974 Indonesian Religious Leader issue a fatwa astray for JAI. At 1999 Presiden Abdurrahman Wahid familiar 
by JAI and the Fatwa MUI dont effect. The role Moslem Television Ahmadiyyah the function to pump up the spirit a organization and religion. At 2000 JAI the sucsesfull inviting supreme leader headquartered from/in London, Hadhrat Mirza Tahir Ahmad come to Indonesia. Mirza invite by Presiden Gus Dur and chairman The People Consultative Assembly of the Indonesia Amien Rais. At 2005 MUI confirm again by fatwa at JAI followed by publication letter joint decision 3 ministry to limit activity JAI and will occur killing zone.

Question this research (1) how prophetic in JAI?, (2) how existence JAI in City Kudus? (3) what culture strategy until zero open conflic in Kudus? This paper for description eksistence JAI in Kudus and strategy until now. JAI is movement purification of Islam, but JAI people in Kudus make strategy by acculturation tradition mayority/nahdliyin, why eksistence JAI until now? Why response nahdliyin at people JAI acculturation tradition nahdliyin? JAI (Qadianian) have motto JAI Love for all hatred for none, humanity first and obey at instruction government. There are 3 things basic accused for JAI (1) injure at Islam and government disbund based on UU No 1/PNPS/1965. The activis human right think, disbund is not suitable by constiitution UUD 1945. Someone suggested JAI treated like in Pakistan and government Indonesia is JAI non-Islam. Suggested forget if Pakistan a Islamis state and Indonesia at basic Pancasila, (2) people JAI right to life in Indonesia and should not disbunder or limited activity perspektive activity HAM. The state to publish SKB minimize to sosialization, and (3) to protect to security people JAI is obligation state.

\section{Discussion}

\subsection{Prophetic in JAI}

The concept prophetic in JAI (1) Prophet SAW dead, appear prophet others until kiamat (prophet buruzi) is prophet dont bring new syariah. This prophet (1) Nabi Shahib asySyari'ah, prophet bring syariah (law) for man, (2) Nabi Mustaqil (servant of God becomes prophet dont follow prophet before) is prophet Musa, (3) Nabi Mustaqil Ghair at-Tasyri' $i$, servant of God becomes prophet don't follow prophet before, don't bring new syariah, God's assignment carry out syariah prophet before is prophet Harun, Daud, Sulaiman, Zakaria, Yahya, and Isa, (4) Nabi Zhilli Ghair at-Tasyri'i (servant God given make prophet because obey on prophet before and to follow syariah prophet before, this level under prophet before and dont bring new syariah). Only prophet bring the syariah only finished because prophet institution closed. Prophet don't bring syariah is persist. Ghulam Ahmad is Nabi Mustaqil Ghair at-Tasyri' $i$ in JAI.

Until 1916 Ahmadiyah baned in India by Syeikh Muhammad Husein al-Battalawi, Maulana Muhammad Ali al-Monkiri (fouding father Nadwatul Ulama India), Syeikh Thana'ullah al-Amritsari, Syeikh Anwar Shah al-Kashmiri, and Seyyed Ata'ullah al-Bukhari al-Amritsari, and Muhammad Iqbal. But, Ministry Ahmadiyah in Pakistan, Zafarullah Khan, to build networking in world. At 1953 the big demonstration in Pakistan and meeting in Karachi attended party and Islamic Organization to birth resolution, Mirza and people Ahmadiyah non-Islam. At 7 September 1974 resolution Majlis National Pakistan reject Ahmadiyah. Background to established Ahmadiyah this predic government Inggris devide at impera muslim in India. Perspective non-Ahmadi, born Ahmadiyah can separated by movement orientalism and colonialism in South Asia especially in India. Figure orientalis Sayyid Ahmad Khan be said, the and of the century-19 Inggris to pra-condisian people India faced by ideas deviasion in Islam. Inggris is colonial devide at impera people and at 23 Maret 
1889 born Ahmadiyah. The movement positive response for public, intruction family nobleman India from Kingdom Moghul, the son of Mirza Ghulam Murtadha by Ciragh Bibi is Mirza Ghulam Ahmad (1839-1908). This family interconection by family Zahiruddin Muhammad Babur, founding Kingdom Mogul (1526-1530). JAI quibble, Mirza write the book are drop trinity azaz in Christiani, the religions mayority in England. Dont logic part of Inggris lift prophet drop trinity and no evidence if funding Ahmadiyah from English. Before standing up Ahmadiyah in India, India this condition instabil. At 1857 India central conflict effect understanding traditional and modern, conflict by sekte and conflict Islam by Kristiani. This time, to discoursus to born figure Imam Mahdi is Mirza Ghulam. After English arrive in India, Hindustan is coloni etnic Sikh and muslim India. Proclamation the religion and free to tabligh, Mirza Ghulam praise English as non-Ahmadi are Sayyid Ahmad Bhrelwi (mujadid 13 century), Syed Ali al-Hariri (ulama Syiah in Hindustan and Syekh Muhammad Abduh). Fund resourches JAI have asset is obligation people are zakat mal (candah).

Ali Mustafa Yaqub (ex-Imam Mosque Istiqlal Jakarta) Ahmadiyah to mix the interpretation al-Quran in al-Baqarah:35 about direction Allah so that Adam occupant in heaven. Word ‘ya Adam' changged 'ya (Mirza Ghulam) Ahmad'. Al-Anfal:17 changed the meaning "ya Ahmad, sent Ghulam from Qadian India, dont: you throw when you throw, but Allah throw", in surat al-Ahzab:40 "Muhammad is don't father from a man, but a prophet and final khotamt". Word 'khotam' this interpreted (by Ahmadiyah) came most glarious as born new prophet pasca prophet Muhammad. Yaqub, Ahmadiyah dodge Mirza Ghulam is mujadid. Amidhan(2011) the basic regret Ahmadiyah (1) name prophet Muhammad change by Ahmad, (2) Islam present in India, don't in Makkah, (3) muslim besides Ahmadiyah considered kafir, (4) if together pray their mosque, washed because of unclean, and (5) Ahmadiyah don't pray makmum by muslim others because non-JAI don't confess JAI.

\subsection{Eksistence JAI in Kudus City}

The factor existance heresy perspective Mahally to effect 3 factors (1) lack of attention to religious leadership religion, (2) the idea heresy to popularity and benefit person, (3) grand design others parties for destroy muslim aqidah. Perspective Pradana, heresy version Peter Clarke (2006) is protest movement from movement others at hegemony group in mainstream to colaboration by political power to monopoly life and actuality believe system and practical religion. If this analys truth, although, Islam mainstream to action self instropection at doctrin, beliefe, practical religions, and dakwa so far don't can empatic from audiens.

Ahmadiyah own 339 branch (level city), conditions for setting up branch JAI minimum a 3 soul are leader, secretary, and bendahara. At Central Java, branch Jateng I teritori in Purwokerto, Tegal, Banyumas, Kebumen, Cilacap, and Brebes. Jateng II in Banjarnegara and Wonosobo, Jateng III in Batang, Kendal, Semarang, Salatiga, Solo, Magelang, Temanggung, Pati, Rembang, Grobogan, and Kudus.

Embrio JAI in Kudus the first, Wakijan, after become a member JAI, he is active to tradition Nahdlatul Ulama, since 1998 become indegeneous religions Rahayu Suci the secretary in Solo. He interested by Rahayu Suci because can to call soul the dead. A than, Wakijan interaction by supranatural form Village Mojolawaran, Pati City is Surosamsuri (Mbah Suro). Mbah Suro to know about Imam Mahdi, Ghulam Ahmad. Wakijan interested because Imam Mahdi considered by teaching community Rahayu Suci. Since Januari 1999 Wakijan sworn in (dibaiat) in Pati from Surosamsuri becomes first JAI in Kudus. After Wakijan sworn in (dibaiat) than Sukardi looking for the inner way of life meet by Suparmin (Ali Muhaimin), kerupuk trader in Colo Village. An than, strengthen from Surosamsuri and 
got match in the heart. That time, Sukardi accused the ampllifier loss in musola in her village. At first, Sukardi dont know Suparmin and Surosamsuri area people JAI from Pati. The argument Sukardi received JAI: teach kindness for the others, public occused about teach JAI because Nabi Muhamad is finished prophet, teaching at al-Quran and hadis, every prophet always antagonized people, loyal at government, and don't prohibition for practical politic in JAI. Principil Sukardi, dont influence the others because the principil life don't same. After that, Sunarko sworn in (dibaiat) at Maret 1999 at forum jalsah salanah (inviting every years internal JAI) in Semarang. After that, Endro sworn in at 1999. Previously, Endro is succes tim at village head election (VHE) in Colo 1998, rivality Susatiyo versus Abdul Kharis, Susatiyo lost in Pilkades Colo. At campaign VHE, if people village Colo, ever learning islamic religion by Mr. Abdul Kharis and don't choose this ustad, the islamic doubtful. This statement, pascaVHE, group Endro lost. After that, Endro create a counter islamic activity to break away group Kiai Abdul Kharis. This new group, embrio JAI in Kudus. The winner Abdul Haris a prediction the winner Islam hijau defeat Islam abangan in Colo.

See after conflict between Endro by NU group, as mother-in-law Endro, Kasminah feel sorry at Endro and become JAI. She is feel inner peace become JAI. Kasmiah that time, consist and active member religion and NU organization this village. And than data, Mulyadi sworn in became JAI at 2000 although four his child and wife dont to join in JAI. The active in JAI because invitation Wakijan. Mulyadi is worker or farmer have Endro. The risk Mulyadi after in JAI, issued from jamiyah every week at NU in sub-village Kumbang, Village Colo. The others data, people don't neighbor and don't family Endro, interested at JAI until 1999 because JAI to teach alms, zakat, and night pray. Tyey are from village Lau, Dawe and wife from Colo Rt.3 by 3 children. But, the child non-JAI. There to people JAI until 2000, don't active because (1) become clearing service in Yayasan Masjid and Makam Sunan Muria, (2) sick, (3) to application education of fellowship his child at JAI dont realization, and (4) impact news about conflic at others area experienced JAI.

At an early stage, at 1999 prayer Jumat in Ratno home. Endro to wakaf the a plot of land 9 x $12 \mathrm{~m}$ for established Masque adz-Dzikr since 2003 until now. Fund from Amir JAI Pusat first periode Rp 10 juta and second periode Rp 5 juta. At 2014, JAI Kudus to buy a plot of land beside Mosque $a d z-D z i k r ~ 424 \mathrm{~m}$ the price Rp 68 juta. The plan land for library. To activity ibadah in mosque for together pray, although people JAI don't active. JAI Kudus receive mubaligh form central JAI, Parung, Bogor to activity JAI. Profesi people JAI are farmer, bisnisman, and enterpreneur. JAI in Kudus since 1999 and become branch JAI 288.

\subsection{Strategy Exsist JAI in Kudus}

JAI di Kudus have strategy to excis intern people. First, to convincing Ahmadi is correct, to together pray and Pray Jumat in mosque JAI, and to continuity donor blood every month joint by Cros Indonesian Read Cross Kudus City come in masque JAI. Second, activity people JAI (1) visiting every years (jalsah salanah), (2) agenda to activity learning al-Quran for child and adults in Masjid adz-Dzikr, but don't realization, (3) the mother activity every month (Mu'awanah) in home people JAI the shifting, (4) a man, pray every days and Jumatan in Masjid JAI Kudus. only pray Jumat is done, (5) an and woman visiting at home people sick or in hospital. The activity accompanied mubaligh JAI.

The existence JAI interaction by non-JAI. First, acculturation the tradition of Nahdliyin in Colo Village, although don't tradition in JAI. People JAI in Kudus to tradition are read manaqib (biografi of Syekh Abdul Qadir Jailani) at forum meeting every month, read Maulid Nabi (history of Nabi SAW) at 1 until 12 Rabiul Awal or every Friday or Sunday in musola, 
visiting of grave at Tuesday, khoul (the event every years to commemorate the dead day). JAI is purification of isalmic, only teach Nabi SAW the activity. Woman JAI in Kudus to activity NU-Muslimah every Friday. Man JAI to activity every Friday to read surah Yasin this village). Second, JAI people fulfill to meet invitation or inviting from NU, are slametan of dead, born, and reception. Mubaligh of JAI from central JAI Pusat (in Parung Bogor) blend in by people non-JAI/Nahdliyin in sosial activity and others. To political bergaining, people JAI at 25 September 2014 to chosen Leader RW 3 Colo Village. Third, if people JAI dead, manner of death vertion NU. Fouth, the home and activity blend in. Fifth, people JAI dont violete positive law, islamic law, and sosial law. Six, to religions activity to invite NU, although don't response. For positive interaction, everi Idul Qurab distribution for NU, Nu distribution for JAI. At Idul Adha 2021, dont qurban donor. Seventh, proaktif at policy government and social activity nahdliyin.

Impact there strategy, first, social life condusive because ekonomic resource is stabil, Second, not easy provocative and NU became not fanatist at JAI. Although, people and activity JAI monitored the movement by muslim figure at statement: "Warga Ahmadiyah dibohke" (JAI left, undisturbed, and dont follower the teach). Third, similarity of relatives family, friends, and neighbors. Fourth, this quantity only 9 head of familyi from 4 thousand people this village. Fifth, people NU dont response fatwa MUI. Because people NU indifferent by fatwa, dont hight tolerance. Sixth, don't islamic organization hard-line and figure NU don't to provocative/locomotive to rival JAI. Seventh, JAI give to understand for public if JAI dont astray by strategy (a) make flyer to distribution at public at 2006 writer God and prophet same (tuhan dan nabinya sama), (b) this mosque writer sentence Laailaha illallah Muhammad Rasulullah, after 10 years exsistance when coflick JAI in Cikeusik, West Java.

Need to be alert, reason conflick (1) if JAI to destribution a book and magazine about teach JAI for public, (2) provocative news in social media can make JAI as target, (3) the present figure to rivality for JAI if growth fanatisme because of suspicion. This agenda, a background JAI dot together NU if pray. An than, the statement figure NU, existance JAI independenly JAI figur by economic hight class. NU figure to prediction at JAI dont growth. First, figure JAI is a middle economy. Second, social caracter people Kudus is sensitive and fanatism about others sekte if growth provocator.

\section{Conclusion}

The existence JAI in Kudus, acculturation the tradition of Nahdliyin in Colo Village, fulfill to meet invitation or inviting from NU, if people JAI dead, manner of death vertion NU, the home and activity blend in (membaur), JAI dont violete positive law, islamic law, and sosial law, to religions acticity to invite NU, although don't response.

Strategy for intern, to convincing Ahmadi is correct, to together pray dan Jumatan in mosque JAI, and to continuity donor blood every month joint by Indonesian Read Cross, activity people JAI (1) visiting every years (jalsah salanah), (2) the mother activity every month (Mu'awanah) in home people JAI the shifting, a man, pray every days and Jumatan in Masjid JAI Kudus, and woman visiting at home people sick or in hospital. 


\section{References}

[1] Ahmad, Munawar. Candy's Bowl: Politik Kerukunan Beragama di Indonesia. Harmoni Jurnal Multikultural dan Multireligius. Puslitbang Kehidupan Keagamaan Badan Litbang dan Diklat Kemenag RI, Vol.12, No.3, September-Desember 2013.

[2] Boy, Pradana. Kegagalan (Dakwah) Islam Mainstream. Jawa Pos, 19 November 2007.

[3] Dzahir, Ihsan Ilahi. Ahmadiah Qodianiyah sebuah Kajian Analitis diterjemahkan dari Al-Qadianiyyah, Dirasat wa Tahlil diterjemahkan oleh Harapandi Dahri. Balitbang Agama Kemenag: Jakarta. 2008.

[4] Mahally, AH. Pemicu Munculnya Aliran Sesat. Republika, 9 November 2007.

[5] Nadwi, Sayid Abul Hasan Ali. 2005. Tikaman Ahmadiyah terhadap Islam. Diterjemahkan dari Qadianism a Critical Study oleh Tubagus Mundzir. Fadlindo Media Utama: Jakarta.

[6] Rosyid. Moh."Ahmadiyah di Kabupaten Kudus", Analisa, Jurnal Pengkajian Masalah Sosial Keagamaan, Vol. XVIII, No.01, Januari-Juni 2011. Balai Litbang, Kemenag, Semarang.

[7] ------ Mendialogkan Ahmadiyah Belajar dari Cikeusik dan Kudus. Neratja Press. 2015.

[8] Sulaeman, Ahmad dan Ekky O. Sabandi. 2014. Klarifikasi terhadap Kesesatan Ahmadiyah dan Plagiator. Edisi Revisi. Neratja Press.

[9] Wahid, Salahuddin. Solusi Ideal Soal Ahmadiyah. Kompas, 9 Februari 2011.

[10] Yaqub, Ali Mustafa. Penodaan Agama. Republika, 18 Februari 2011.

[11] Zulkarnain, Iskandar. 2005. Gerakan Ahmadiyah di Indonesia. LKiS: Yogyakarta. 